\title{
Pengaruh Peningkatan Kapasitas Tahap Esterifikasi Minyak Kemiri Sunan (Reutalis trisperma) sebagai Bahan Baku Produksi Biodiesel
}

\author{
Capacity Improvement at Esterification on Kemiri Sunan (Reutalis trisperma) Oil as Raw Material of Biodiesel \\ Eki Dwiyan Saputra ${ }^{1 *}$, Sarifah Nurjanah², Haryono $^{3}$, Ade Moetangad Kramadibrata $^{2}$, Efri Mardawati², Wahyu Daradjat ${ }^{4}$, \\ Handarto $^{2}$, Totok Herwanto ${ }^{2}$, S. Rosalinda², Muhammad Saukat ${ }^{2}$, Dedy Prijatna ${ }^{2}$ \\ ${ }^{1}$ Mahasiswa Departemen Teknik Pertanian dan Biosistem, Fakultas Teknologi Industri Pertanian, Universitas Padjadjaran \\ ${ }^{2}$ Staf Pengajar Fakultas Teknologi Industri Pertanian, Universitas Padjadjaran \\ ${ }^{3}$ Staf Pengajar Departemen Kimia Fakultas Matematika dan IPA, Universitas Padjadjaran \\ ${ }^{4}$ Staf Pengajar Fakultas Pertanian, Universitas Padjadjaran \\ Jalan Raya Bandung - Sumedang KM.21, Jatinangor 45362, Jawa Barat \\ *E-mail: joeki1996@gmail.com
}

Diterima: 12 Agustus 2018; Disetujui: 12 Desember 2019

\begin{abstract}
ABSTRAK
Ketergantungan terhadap bahan bakar fosil menjadi permasalahan utama yang sedang terjadi. Biodiesel merupakan energi terbarukan berasal dari minyak nabati yang dapat mengurangi ketergantungan pada bahan bakar fosil. Kemiri sunan (Reutalis trisperma) merupakan salah satu tanaman yang bisa digunakan menjadi bahan baku pembuatan biodiesel. Karena nilai ALB (Asam Lemak Bebas) yang tinggi menyebabkan reaksi esterifikasi harus dilakukan. Penelitian ini bertujuan untuk mengetahui pengaruh peningkatan kapasitas terhadap mutu dan rendemen dari minyak kemiri sunan pada proses esterifikasi. Metode penelitian yang digunakan adalah metode deskriptif dengan analisis korelasi regresi. Esterifikasi dilakukan dengan menggunakan lima perlakuan kapasitas yaitu $A=200 \mathrm{~mL} ; B=400 \mathrm{~mL} ; C=600 \mathrm{~mL} ; \mathrm{D}=800 \mathrm{~mL}$; dan $\mathrm{E}=$ $1000 \mathrm{~mL}$. Parameter mutu yang diuji pada penelitian ini adalah rendemen, densitas, viskositas kinematik, bilangan asam dan ALB, kadar air, indeks bias, dan warna. Hasil penelitian menunjukan peningkatan kapasitas pada proses esterifikasi mempengaruhi mutu minyak. Perlakuan E merupakan hasil terbaik yang diperoleh, karena memiliki nilai terbaik pada 5 parameter dari 8 parameter keseluruhan. Perolehan nilai rendemen, bilangan asam, ALB, densitas, viskositas kinematik, indeks bias dan warna ( ${ }^{\circ} \mathrm{HUE}$ ) pada perlakuan $\mathrm{E}$ secara berturut adalah 82,04\%, 2,9702 $\mathrm{mg}-\mathrm{KOH} / \mathrm{g}-\mathrm{minyak}, 4,61 \%, 0,9486$ $\mathrm{g} / \mathrm{cm}^{3}, 4,94 \mathrm{~mm}^{2} / \mathrm{s}, 0,9939 \%, 0,0008951$, dan 87,47991 (Yellow Red).
\end{abstract}

Kata kunci: biodiesel; kemiri sunan; esterifikasi; peningkatan kapasitas

\section{ABSTRACT}

Biodiesel is a renewable energy derived from vegetable oils that can reduce dependence on fossil fuels. Kemiri sunan (Reutalis trisperma) is one of the plants that can be used as raw material for biodiesel. The high FFA (Free Fatty Acid) value of kemiri sunan oil lead to an esterification reaction before transesterification. This study aims to determine the effect of capacity improvement in esterification process on the quality and yield. The research method used is descriptive method with regression correlation as the advanced analysis. Esterified was conducted in five capacity treatment that are $A=200$ $\mathrm{mL} ; B=400 \mathrm{~mL} ; C=600 \mathrm{~mL} ; D=800 \mathrm{~mL}$; and $E=1000 \mathrm{~mL}$ with the parameters of yield, density, kinematic viscosity, acid number and $A L B$, water content, refractive index, and color. The results showed that the capacity improvement of esterification process affected the oil quality. Treatment $E$ is the best result obtained, because it has the best value on the 5 parameters of the 8 overall parameters with the number of its yield, acid number, FFA, density, kinematic viscosity, refractive index and color ( $\left.{ }^{\circ} \mathrm{HUE}\right)$ were $2.970 \mathrm{mg}-\mathrm{KOH} / \mathrm{g}$-oil, $1,43 \%, 0.948 \mathrm{~g} / \mathrm{cm}^{3}, 4.94 \mathrm{~mm}^{2} / \mathrm{s}, 0.994 \%, 0.0008951$, and 87.479 (Yellow Red), respectively.

Keywords: biodiesel; kemiri sunan, esterification, capacity improvement.

\section{PENDAHULUAN}

Di Indonesia ketergantungan terhadap bahan bakar fosil bisa dikatakan sangat tinggi hal ini terlihat dari bauran sumber energi yang digunakan di Indonesia. Menurut Dewan Energi Nasional (2016) bahan bakar fosil merupakan sumber energi bahan bakar utama yang digunakan (62 juta TOE), diikuti oleh gas (25 juta TOE), listrik (17 juta TOE), batubara (17 juta TOE), dan energi terbarukan yang digunakan sebesar 8 juta TOE.

Krisis energi yang terjadi, dan dampak buruk yang diberikan bahan bakar fosil pada lingkungan mendorong pengembangan energi alternatif yang berasal dari sumber daya energi yang dapat diperbarui (renewable resources). Diversifikasi penggunaan energi dengan memanfaatkan sumber energi yang ada disekitar kita, diharapkan dapat mengurangi ketergantungan terhadap sumber bahan bakar fosil (Kholiq, 2015). Salah satu sumber energi terbarukan yang dapat dikembangkan tersebut adalah biodiesel.

Biodiesel adalah bahan bakar alternatif yang dibuat dari bahan atau sumber daya yang terbarukan (renewable). Pada umumnya bahan yang digunakan dalam memproduksi biodiesel minyak kelapa sawit, minyak kelapa, minyak jarak pagar, minyak biji kapuk, minyak 
kemiri sunan dan 29 bahan lain yang berpotensi dijadikan bahan baku biodiesel (Darmawan dan Susila, 2013; Mulyana dan Asti, 2013). Biodiesel diproduksi dari minyak nabati adalah dengan cara mengubah trigliserida yang merupakan komponen utama minyak nabati menjadi metil ester asam lemak, dengan memanfaatkan katalis melalui proses transesterifikasi (Nurjanah dkk, 2015; Nurjanah, dkk 2019; Haryanto, 2013; Darmawan dan Susila, 2013).

Kemiri sunan (Reutalis trisperma) merupakan komoditas penghasil minyak yang bersifat non edible (tidak dapat dikonsumsi) dan bersifat racun sehingga mempunyai potensi sebagai bahan baku biodiesel. Menurut Djenar dan Lintang (2012), minyak kemiri sunan kasar hasil ekstraksi memiliki nilai bilangan asam $(137,41 \mathrm{mgKOH} / \mathrm{g}$ minyak) yang tergolong tinggi sehingga menyebabkan perolehan metil ester (biodiesel) memiliki rendemen yang rendah dan minyak kemiri sunan pun belum memenuhi Syarat Mutu Biodiesel Indonesia (SNI 7182:2015). Oleh karena itu perlu dilakukan proses esterifikasi yang berfungsi untuk menurunkan kandungan ALB (Free Fatty acid) atau asam lemak bebas yang ada pada minyak kemiri sunan kasar, sehingga nantinya rendemen minyak biodiesel hasil transesterifikasi menjadi lebih maksimal.

Hasil penelitian sebelumnya tentang proses esterifikasi pada pembuatan biodiesel dilakukan pada kapasitas yang kecil, sehingga diperlukan penelitian peningkatan kapasitas bahan pada proses esterifikasi terhadap mutu dan rendemen produk yang dihasilkan. Penelitian ini bertujuan untuk mengkaji pengaruh peningkatan kapasitas proses esterifikasi dari kapasitas $200 \mathrm{~mL}$ sampai $1000 \mathrm{~mL}$ terhadap rendemen, bilangan asam, ALB, densitas, viskositas kinematik, indeks bias dan warna produk yang dihasilkan. Dari hasil pengujian bisa didapatkan suatu persamaan yang dapat digunakan untuk mengestimasi nilai mutu yang diinginkan agar sesuai harapan.

\section{METODOLOGI PENELITIAN}

\section{Bahan dan Alat}

Bahan penelitian yang digunakan adalah kemiri sunan yang didapat dari Desa Cinunuk, Kecamatan Wanaraja, Kabupaten Garut. Bahan kimia yang digunakan antara lain metanol, Asam Sulfat $\left(\mathrm{H}_{2} \mathrm{SO}_{4}\right), \mathrm{KOH} \quad 0,1$, indikator fenolftalein dan aquades.

Alat-alat yang digunakan pada penelitian ini antara lain mesin pengering, mesin pemecah kemiri sunan, mesin pengepres kemiri sunan, piknometer, waterbath, timbangan analitik, erlenmeyer, refractometer Abbe, hotplate magnetic stirrer, corong pemisah, dan gelas ukur.

\section{Metode}

Metode yang digunakan pada penelitian ini adalah metode deskriptif dengan analisis lanjutan korelasi regresi. Kapasitas yang digunakan pada proses esterifikasi dilakukan dengan lima taraf perlakuan yaitu perlakuan $A=$ kapasitas $200 \mathrm{~mL}$; $\mathrm{B}=$ kapasitas $400 \mathrm{~mL}$; $\mathrm{C}=$ kapasitas $600 \mathrm{~mL} ; \mathrm{D}=$ kapasitas $800 \mathrm{~mL}$; dan $\mathrm{E}=$ kapasitas $1000 \mathrm{~mL}$. Percobaan dilakukan sebanyak tiga kali ulangan. Parameter yang dikaji adalah rendemen, bilangan asam, ALB, densitas, viskositas kinematik, indeks bias dan warna produk yang dihasilkan

\section{Tahapan Penelitian}

\section{Persiapan Bahan}

Sortasi dilakukan untuk mendapatkan kemiri sunan yang baik (tidak busuk dan tidak berjamur). Kemiri sunan yang telah disortasi selanjutnya dikeringkan dengan menggunakan sinar matahari dilanjutkan dengan pengeringan menggunakan oven. Kemiri sunan yang telah kering selanjutnya dipress untuk mendapatkan minyak kemiri sunan yang digunakan sebagai bahan baku proses esterifikasi.

\section{Proses Esterifikasi}

Minyak kemiri sunan pada setiap perlakuan dicampur metanol dengan rasio mol metanol dan minyak sebesar 6:1 dan katalis asam sulfat $\left(\mathrm{H}_{2} \mathrm{SO}_{4}\right)$ dengan konsentrasi $1 \%$ (v/v) ke dalam wadah reaksi. Campuran selanjutnya diaduk kecepatan pengadukan $600 \mathrm{rpm}\left(\right.$ suhu $60^{\circ} \mathrm{C}$ ) selama 2 jam sehingga terbentuk minyak campuran antara trigliserida, metil ester, gum, dan air. Mengendapkan campuran dalam corong pemisah dilakukan selama 60 menit sehingga akan terbentuk dua lapisan pada campuran. Trigliserida dan metil ester dipisahkan dari campuran dengan corong pemisah. Pencucian selanjutnya dilakukan dengan menggunakan akuades.

\section{Analisis mutu dan perhitungan rendemen}

Analisis mutu yang dilakukan adalah penentuan bilangan asam, Asam Lemak Bebas (ALB), viskositas kinematik, kadar air, densitas, warna dan indeks bias. Pengujian dilakukan dengan mengacu pada SNI 7182:2015. Rendemen diukur dengan cara membandingkan produk yang berupa minyak sesudah proses esterifikasi dengan minyak sebelum proses esterifikasi.

\section{Penentuan Persamaan Korelasi Regresi}

Penentuan persamaan yang akan digunakan untuk estimasi nilai mutu dilakukan dengan menggunakan software Microsoft Excel. Hubungan antara nilai variabel $x$ (kapasitas) dan variabel y (mutu) dibuat grafik. Dari grafik yang terbentuk ditentukan jenis persamaan yang akan digunakan (eksponensial, linear, logaritmik, polynomial, power) dengan melihat nilai koefisien determinansi tertinggi.

\section{HASIL DAN PEMBAHASAN}

\section{Karakteristik Minyak Kemiri Sunan}

Pengujian karakteristik minyak kemiri sunan dilakukan dengan tujuan untuk mengetahui kondisi awal minyak kemiri sunan yang akan digunakan menjadi bahan baku proses esterifikasi. Karakteristik minyak kemiri sunan disajikan pada Tabel 1

Hasil pengujian bilangan asam dan ALB menunjukan nilai yang cukup tinggi dimana untuk nilai bilangan asam adalah sebesar $43,096 \mathrm{mg} \mathrm{KOH} / \mathrm{g}$ minyak sedangkan untuk nilai ALB adalah sebesar 21,323\%. Menurut Pranowo (2014) nilai bilangan asam tidak boleh lebih dari $5 \mathrm{mg}$ $\mathrm{KOH} / \mathrm{g}$ minyak sedangkan nilai ALB sebaiknya dibawah nilai $2-3 \%$. Tingginya bilangan asam dan ALB ini maka dibutuhkan perlakuan pretreatment berupa esterifikasi untuk menurunkan nilai dari bilangan asam dan ALB.

Nilai kadar air yang terdapat pada minyak kemiri sunan kasar adalah sebesar $24,928 \%$. Nilai kadar air yang tinggi dapat menjadi kendala selama proses produksi biodiesel terutama pada tahapan transesterifikasi karena dapat memperbesar kemungkinan terjadinya reaksi saponifikasi yang mengurangi jumlah trigliseridan yang terkonversi menjadi FAME (Atadashi et al., 2012). Selain itu jika kadar air minyak terlalu besar dapat mempercepat hidrolisis pada minyak

Nilai viskositas kinematik bahan sebesar $13,845 \mathrm{~mm}^{2} / \mathrm{s}$, nilai viskositas yang tinggi tidak baik dimiliki oleh bahan baku biodiesel. Nilai viskositas kinematik yang tinggi dapat menyebabkan pemisahan pengotor dari bahan menjadi sulit dilakukan (Pawoko, 2009). 
Tabel 1. Karakteristik Minyak Kemiri Sunan Sebelum Esterifikasi

\begin{tabular}{lll}
\hline Parameter & Satuan & Minyak Kemiri Sunan \\
\hline Bilangan Asam & $\mathrm{mg} \mathrm{KOH} / \mathrm{g}$ minyak & 43,096 \\
Asam Lemak Bebas (ALB) & $\%$ & 21,323 \\
Viskositas Kinematik $\left(40^{\circ} \mathrm{C}\right)$ & $\mathrm{mm}^{2} / \mathrm{s}$ & 13,845 \\
Kadar Air & $\%-w b$ & 24,928 \\
Densitas & $\mathrm{g} / \mathrm{cm}^{3}$ & 0,966 \\
Indeks Bias & - & $8,989 \times 10^{-4}$ \\
Warna & oHUE & 86,704 \\
& & (Yellow Red) \\
\hline
\end{tabular}

Nilai densitas dari minyak kemiri sunan kasar adalah sebesar $0,9662 \mathrm{~g} / \mathrm{cm}^{3}$. Komponen asam lemak yang ada didalam kemiri sunan mempengaruhi nilai dari densitas semakin jenuh minyak maka semakin besar nilai densitasnya (Altun et al., 2010). Nilai densitas juga erat kaitannya dengan tingkat kontaminasi minyak semakin besar nilai densitas semakin tinggi kontaminasi yang ada pada bahan (Barabas dan Todorut, 2011).

Nilai indeks bias minyak kemiri sunan adalah 8,989 $\mathrm{x}$ $10^{-4}$, indeks bias menunjukan tingkat kejernihan dari bahan semakin rendah nilai indeks bias semakin jernih kondisi minyak kemiri sunan. Minyak kemiri sunan memiliki nilai oHUE 86,704 yang berarti minyak kemiri sunan memiliki warna kromatis yellow read.

\section{Rendemen Esterifikasi}

Rendemen esterifikasi merupakan perbandingan produk sesudah proses esterifikasi dengan minyak kemiri sunan sebagai bahan baku proses esterifikasi. Rendemen esterifikasi pada beberapa kapasitas proses esterifikasi disajikan pada Gambar 1.

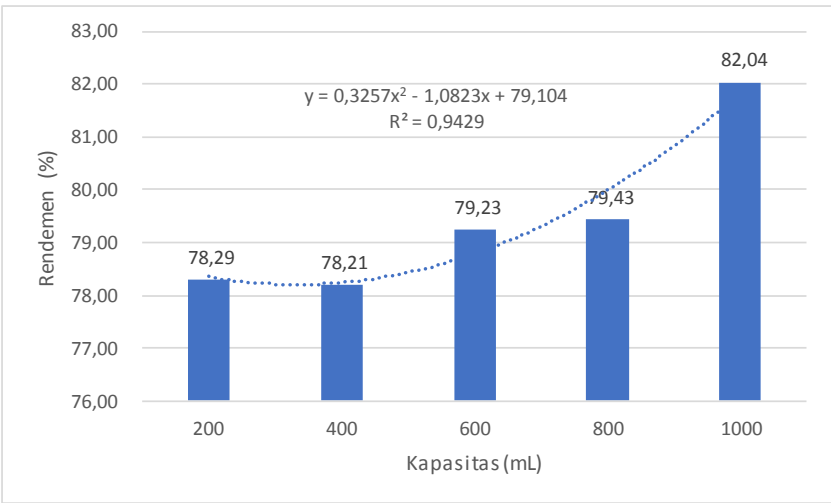

Gambar 1.Grafik Hubungan antara Kapasitas dan Rendemen pada Proses Esterifikasi

Hasil penelitian menunjukkan bahwa rendemen meningkat dengan peningkatan kapasitas, semakin besar kapasitas yang digunakan, semakin tinggi nilai rendemen yang dihasilkan. Hal tersebut mengindikasikan kondisi operasi yang digunakan sesuai untuk reaksi esterifikasi pada kapasitas semakin tinggi yang ditandai dengan nilai rendemen tertinggi ada pada perlakuan kapasitas $1000 \mathrm{~mL}$. Semakin besar kapasitas yang digunakan semakin efektif reaksi yang terjadi yang mengakibatkan konversi asam lemak bebas ke metil ester menjadi lebih sempurna. Peningkatan rendemen tersebut mengikuti persamaan y $=$ $0,3257 x^{2}-1,0823 x+79,104$ dengan nilai $R^{2}=0,9429$ yang berarti bahwa $94 \%$ rendemen dipengaruhi oleh kapasitas.

\section{Analisis Mutu Minyak Hasil Proses Esterifikasi}

\section{Bilangan Asam}

Bilangan asam merupakan jumlah $\mathrm{KOH}$ yang diperlukan untuk dapat menetralisir asam dalam bahan. Nilai ini mengindikasikan banyaknya kandungan asam lemak bebas pada bahan. Hasil pengujian bilangan asam pada hasil esterifikasi pada beberapa kapasitas disajikan pada Gambar 2.

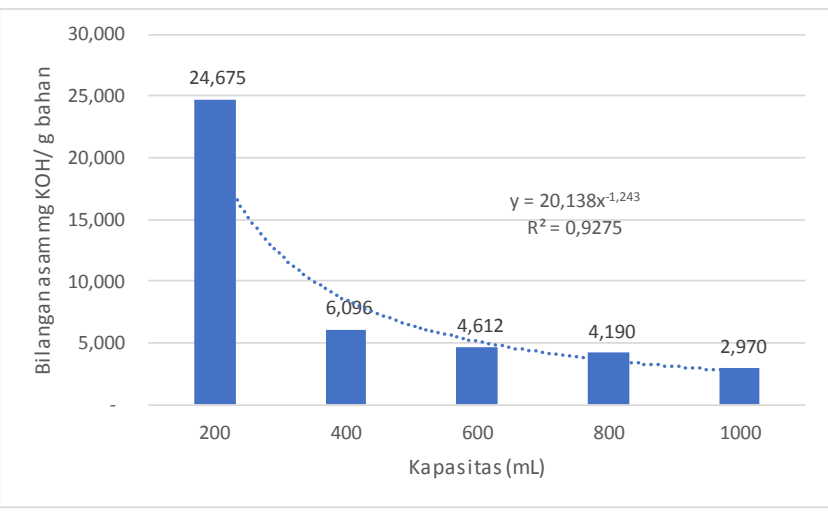

Gambar 2. Grafik Hubungan Kapasitas dan Bilangan Asam

Hasil penelitian menunjukkan bahwa nilai dari bilangan asam menurun setelah dilakukan proses esterifikasi. Penurunan nilai bilangan asam pada reaksi esterifikasi diakibatkan terkonversinya asam lemak bebas yang ada pada minyak menjadi metil ester (Knothe et al., 2005). Semakin besar kapasitas minyak yang diolah semakin kecil nilai bilangan asam yang dihasilkan, hal tersebut diakibatkan kondisi operasi yang diterapkan pada reaksi esterifikasi semakin optimum seiring meningkatnya kapasitas yang digunakan.

Kecepatan putaran pengadukan pada saat proses esterifikasi digunakan 600 rpm untuk semua kapasitas. Pada kapasitas rendah nilai bilangan asam masih cukup tinggi, hal ini diduga karena tingginya suhu selama proses esterifikasi yang disebabkan oleh kecepatan putaran tersebut. Menurut Sari dan Lestari (2015) kecepatan putar akan menyebabkan peningkatan suhu yang cukup signifikan pada sampel. Peningkatan suhu pada proses esterifikasi akan menyebabkan metanol yang digunakan sebagai reaktan menguap dan menyebabkan reaksi esterifikasi menjadi tidak optimal. Penurunan bilangan asam mengikuti persamaan $y=20,138 x^{-1,243}$ dengan nilai $R^{2}$ $=0,9275$. Hal ini berarti bahwa 92,72 \% penurunan bilangan asam dipengaruhi oleh peningkatan kapasitas.

\section{Kadar ALB}

Kadar ALB merupakan banyaknya asam lemak bebas pada bahan. Tujuan utama proses esterifikasi adalah menurunkan atau menghilagkan asam lemak bebas pada 
minyak yang digunakan dalam proses transesterifikasi. Kadar ALB yang sangat tinggi pada bahan baku pembuatan biodiesel akan bereaksi dengan katalis dan menghasilkan sabun, yang mengakibatkan turunnya nilai rendemen dalam proses transesterifikasi (Knothe et al, 2015). Hasil pengujian nilai ALB pada beberapa kapasitas disajikan pada Gambar 3.

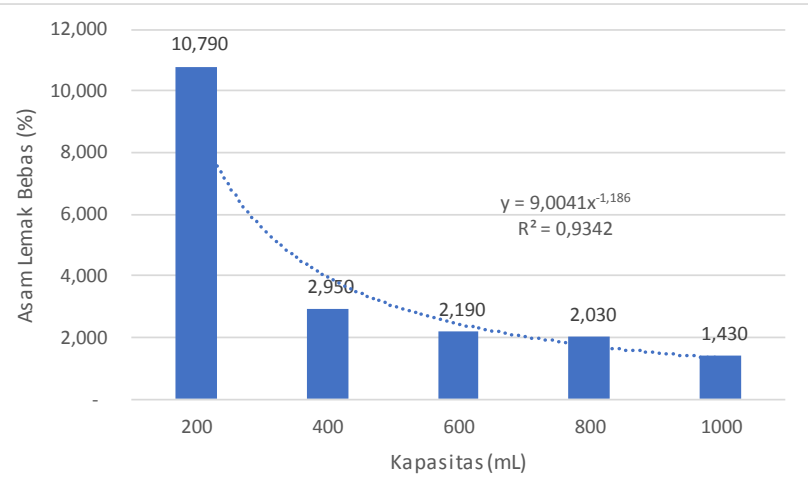

Gambar 3. Grafik Hubungan Kapasitas dan Kadar ALB

Hasil penelitian menunjukkan bahwa reaksi esterifikasi dapat secara efektif menurunkan kadar ALB pada bahan. Jika diperhatikan semakin besar kapasitas yang digunakan pada reaksi esterifikasi semakin kecil kadar ALB yang dimiliki bahan, hal tersebut mengindikasikan kondisi operasi yang diterapkan pada reaksi esterifikasi semakin baik mengonversi asam lemak bebas menjadi metil ester jika kapasitas yang digunakan semakin besar. Nilai ALB yang tinggi pada kapasitas $200 \mathrm{~mL}$ diakibatkan oleh adanya pergeseran kondisi operasi yang disebabkan tingginya kecepatan putar reaksi sebesar $600 \mathrm{rpm}$ yang membuat suhu campuran naik dan menyebabkan metanol menguap sehingga tidak dapat bereaksi secara maksimal dengan asam lemak pada minyak. Minyak hasil pada kapasitas 400 $\mathrm{mL}$ sampai $1000 \mathrm{~mL}$ dapat diolah lebih lanjut dengan proses transesterifikasi karena mengandung kadar ALB dibawah 3\%, dimana menurut Hikmah dan Zuliyana (2010) bahan baku biodiesel siap diolah apabila memiliki kadar ALB maksimal 3\%. Penurunan kadar ALB mengikuti persamaan $y=9,0041 x^{-1,18}$ dengan nilai $R^{2}=0,9342$. Hal ini berarti bahwa 93,42 \% penurunan kadar ALB dipengaruhi oleh peningkatan kapasitas.

\section{Densitas}

Densitas merupakan perbandingan antara berat minyak dengan volumenya. Hasil penelitian nilai densitas pada beberapa kapasitas proses esterifikasi disajikan pada Gambar 4.

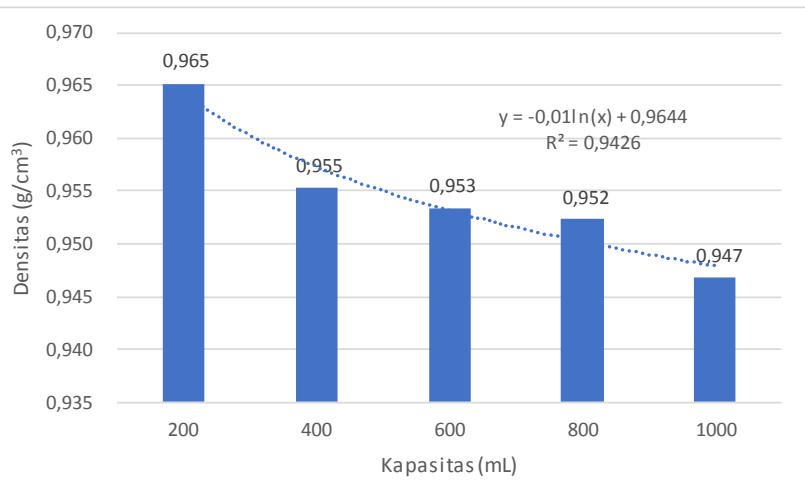

Gambar 4. Grafik Hubungan Kapasitas dan Densitas
Hasil penelitian menunjukkan bahwa densitas bahan menurun dengan adanya peningkatan kapasitas proses esterifikasi. Hal itu disebabkan kondisi operasi pada reaksi esterifikasi dapat semakin maksimal mengurangi kandungan gliserol pada bahan apabila dilakukan pada kapasitas yang lebih besar. Nilai densitas dipengaruhi oleh kandungan gliserol pada bahan dan tingkat kemurnian produk. Densitas gliserol sebesar $1,26 \mathrm{~g} / \mathrm{cm}^{3}$. Semakin besar kapasitas maka reaksi menjadi semakin efektif sehingga densitasnya menjadi semakin turun. Semakin kecil nilai densitas menunjukkan semakin kecil tingkat kontaminasi dari minyak tersebut (Barabas dan Todorut, 2011). Menurut SNI 7182:2015 nilai maksimum dari densitas adalah $0,89 \mathrm{~g} / \mathrm{cm}^{3}$. Pada kapasitas $1000 \mathrm{~mL}$ nilai densitasnya telah memenuhi persyaratan SNI untuk biodiesel. Penurunan densitas mengikuti persamaan $\mathrm{y}=-$ $0,01 \ln (x)+0,9644$ dengan nilai $R^{2}=0,9426$. Hal ini berarti bahwa $94,26 \%$ penurunan densitas dipengaruhi oleh peningkatan kapasitas.

\section{Kadar Air}

Kadar air merupakan persentase kandungan air dalam bahan. Hasil penelitian kadar air bahan pada beberapa kapasitas proses esterifikasi disajikan pada Gambar 5.

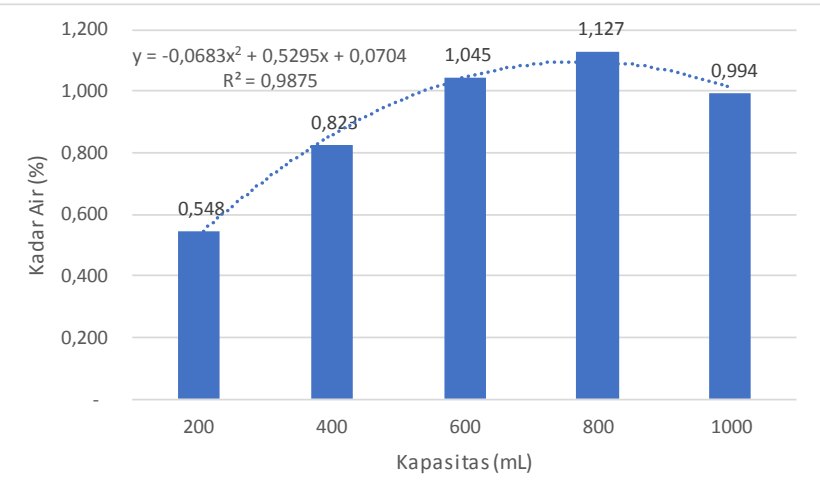

\section{Gambar 5. Grafik Hubungan Kapasitas dan Kadar Air}

Hasil penelitian menunjukkan bahwa reaksi esterifikasi dapat menurunkan nilai kadar air pada bahan, hal tersebut dikarenakan selama reaksi esterifikasi reaksi antara asam lemak dan metanol akan menghasilkan metil ester dan air (Knothe et al, 2005) dimana air yang merupakan bahan yang tidak diinginkan dipisahakan dari metil ester. Nilai kadar air yang tinggi pada bahan dapat merugikan karena dapat mempercepat terjadinya reaksi hidrolisis dan pertumbuhan mikroba (Atadashi et al., 2012) dan dapat meningkatkan kadar ALB biodiesel (Pranowo dkk, 2014). Menurut Gerpen et al (2004), kandungan maksimum kadar air dari minyak bahan baku biodiesel adalah 7\%. Hasil penelitian menunjukkan bahwa semua sampel memiliki kadar air dibawah 7\% hal tersebut mengindikasikan bahwa minyak hasil esterifikasi dilanjut pencucian bisa diolah lebih lanjut ke tahap transesterifikasi. Perubahan kadar air mengikuti persamaan $y=-0,0683 x^{2}+0,5295 x+0,0704$ dengan nilai $R^{2}=0,9875$. Hal ini berarti bahwa 98,75\% perubahan kadar air dipengaruhi oleh peningkatan kapasitas.

\section{Viskositas Kinematik}

Viskositas merupakan ketahanan aliran suatu cairan yang diakibatkan karena adanya gesekan internal antara cairan bergerak dengan cairan yang diam. Hasil penelitian pengujian viskositas kinematik pada beberapa kapasitas proses esterifikasi disajikan pada Gambar 6 . 


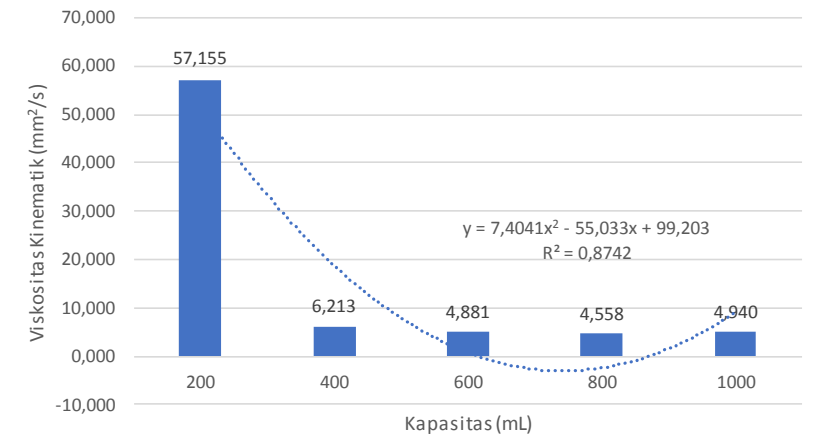

(a)

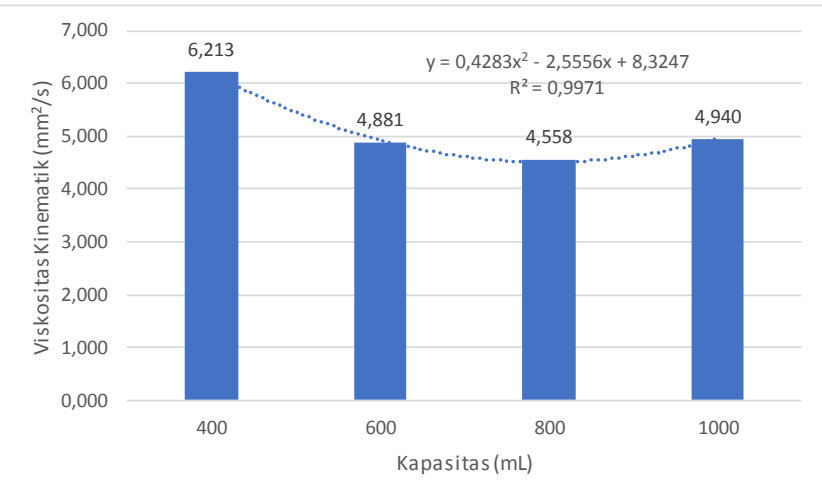

(b)

Gambar 6. Grafik Hubungan Kapasitas dan Viskositas Kinematik: pada lima kapasitas (a) dan pada empat kapasitas (b)

Hasil penelitian menunjukkan bahwa proses esterifikasi dapat menurunkan nilai viskositas kinematik pada minyak kapasitas 400 hingga 1000 mL. Turunnya nilai viskositas kinematik diakibatkan oleh terkonversinya asam lemak bebas pada bahan menjadi metil ester yang memiliki rantai asam lemak lebih pendek. Nilai viskositas erat kaitannya dengan komposisi asam lemak yang terkandung dalam bahan, semakin panjang rantai asam lemak bahan semakin tinggi nilai viskositasnya (Djenar dan Lintang, 2012). Pada kapasitas $200 \mathrm{~mL}$ kondisi operasi yang tidak sesuai (kecepatan putar reaksi 600 rpm) mengakibatkan pengotor yang sudah terpisah selama reaksi terjadi menjadi tercampur kembali dan mengakibatkan terbentuknya emulsi sehingga membuat minyak esterifikasi menjadi kental dan memiliki nilai viskositas kinematik yang tinggi.

Model persamaan untuk viskositas kinematik dilakukan pada lima tingkat kapasitas dan empat kapasitas. Hal ini dilakukan karena pada kapasitas terkecil $(200 \mathrm{~mL})$ nilai viskositas kinematik sangat berbeda dengan lainnya sehingga persamaan viskositas kinematik pada empat kapasitas lainnya dihitung sendiri. Perubahan viskositas kinematik pada kelima sampel (a) mengikuti persamaan $\mathrm{y}=$ $7,4041 x^{2}-55,033 x+99,203$ dengan nilai $R^{2}=0,8742$. Hal ini berarti bahwa $87,42 \%$ perubahan viskositas kinematik dipengaruhi oleh peningkatan kapasitas. Perubahan viskositas kinematik pada empat sampel (b) mengikuti persamaan $y=0,4283 x^{2}-2,5556 x+8,3247$ dengan nilai $R^{2}$ $=0,9971$. Hal ini berarti bahwa 99,71 \% perubahan viskositas kinematik dipengaruhi oleh peningkatan kapasitas.

\section{Indeks Bias}

Indeks bias menggambarkan banyaknya cahaya yang melewati media, dimana sinar akan membias dari garis normal. Hasil penelitian indeks bias minyak hasil esterifikasi pada berbagai kapasitas disajikan pada Gambar 7.

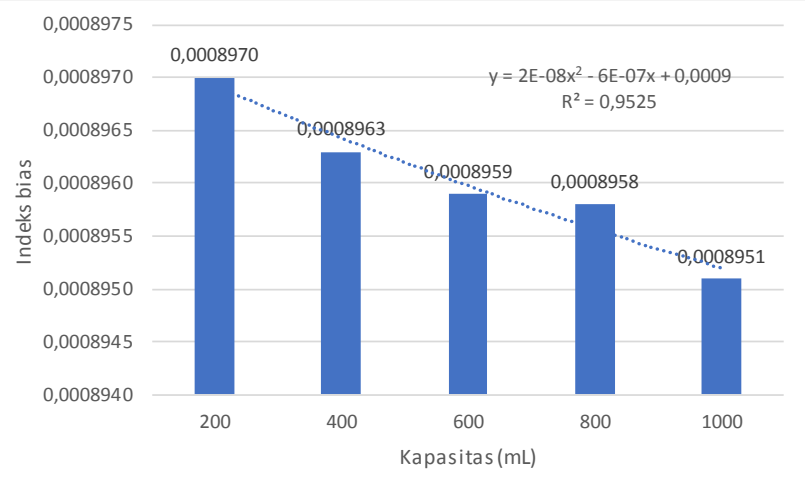

Gambar 7. Grafik Hubungan Kapasitas dengan Indeks Bias

Hasil penelitian menunjukkan bahwa reaksi esterifikasi dapat menurunkan nilai indeks bias. Semakin besar kapasitas yang digunakan semakin kecil nilai indeks bias yang dihasilkan. Hal tersebut diakibatkan oleh kondisi operasi esterifikasi yang diterapkan akan semakin optimum apabila digunakan pada kapasitas yang lebih besar. Esterifikasi pada kapasitas kapasitas $1000 \mathrm{~mL}$ menghasilkan minyak dengan tingkat kejernihan paling baik karena memiliki nilai indek bias paling kecil. Indeks bias merupakan satu sifat optis yang dapat digunakan untuk mementukan kemurnian dari minyak (Hidayanto dkk, 2010). Semakin rendah nilai indeks bias maka semakin tinggi kemurnia suatu bahan. Perubahan indeks bias mengikuti persamaan $y=2 E-08 x^{2}-6 E-07 x+0.0009$ dengan nilai $R^{2}$ $=0,9525$. Hal ini berarti bahwa 95,25 \% perubahan indeks bias dipengaruhi oleh peningkatan kapasitas.

\section{Warna}

Pengujian warna dilakukan dengan tujuan mengetahui perubahan warna yang terjadi pada sampel setelah dilakukan reaksi esterifikasi dan pencucian esterifikasi. Hasil penelitian warna minyak sesudah proses esterifikasi pada beberapa kapasitas disajikan pada Gambar 8.

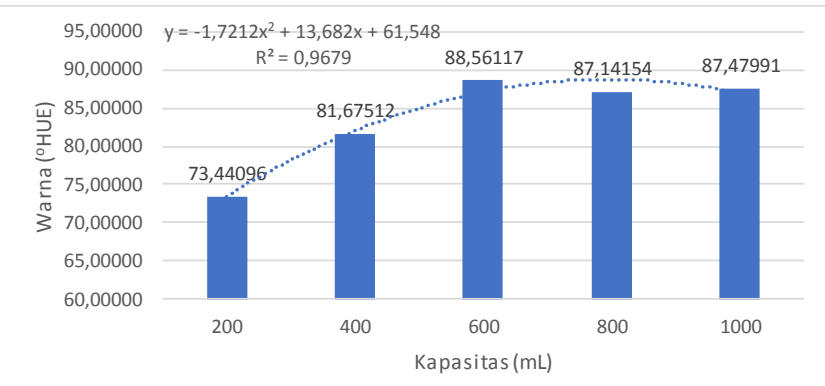

Gambar 8. Grafik Hubungan Kapasitas dan Warna

Dari Gambar 8 diketahui bahwa tidak terdapat perbedaan yang cukup signifikan diantara minyak kemiri sunan dengan minyak esterifikasi dan hasil pencucian esterifikasi dimana nilai ${ }^{\circ} \mathrm{HUE}$ berkisar pada nilai $73-88$ dimana rentan nilai oHUE memiliki warna kromatis Yellow Red. Perbedaan tinggi rendahnya nilai oHUE diakibatkan oleh nilai $L^{*}$ yang mempengaruhi kecerahan dari sampel minyak yang dihasilkan. Semakin rendah nilai $L^{*}$ semakin gelap warna dari minyak yang dihasilkan. 


\section{KESIMPULAN}

Peningkatan kapasitas proses esterifikasi mempengaruhi rendemen, bilangan asam, kadar asam lemak bebas (ALB), kadar air, viskositas kinematik, indeks bias dan warna minyak yang dihasilkan. Model persamaan untuk parameter rendemen, bilangan asam, kadar asam lemak bebas (ALB), kadar air, viskositas kinematik, indeks bias dan warna adalah $y=0,3257 x^{2}-1,0823 x+79,104, y=$ $9,0041 x^{-1,18}, y=9,0041 x^{-1,18}, y=-0,01 \ln (x)+0,9644, y=-$ $0,0683 x^{2}+0,5295 x+0,0704, y=2 E-08 x^{2}-6 E-07 x+$ $0.0009, y=2 E-08 x^{2}-6 E-07 x+0.0009, y=-1,7212 x 2+$ $13,682 x+61,548$. Berdasarkan hasil yang diperoleh maka dapat disimpulkan bahwa minyak terbaik didapatkan dari reaksi esterifikasi pada kapasitas $1000 \mathrm{~mL}$ karena menghasilkan rendemen proses tertinggi $(82,04 \%)$, nilai bilangan asam terendah (2,9702 $\mathrm{mg} \mathrm{KOH} / \mathrm{g}$ minyak), ALB terendah $(1,43 \%)$, nilai densitas terendah $\left(0,9486 \mathrm{~g} / \mathrm{cm}^{3}\right)$, dan indeks bias terendah $(0,0008951)$.

\section{UCAPAN TERIMAKASIH}

Ucapan terimakasih disampaikan kepada Rektor Unpad atas pendanaan pada proyek Academic Leaderships Grant (ALG).

\section{DAFTAR PUSTAKA}

Altun, S., Yasar, F., Oner, C. 2010. The Fuel Properties of Methyl Ester Produced from Canola Oil-Animal Tallow Blends by Base-Catalyzed Transesterification. Interntional Journal of Engineering Research and Development 2(2): pp. 2-5

Atadashi, I.M., Aroua, M.K., Abdul Aziz, A.R., Sulaiman, N.M.N. 2011. Refining Technologies for The Purification of Crude Biodiesel. Applied Energy 88(2011): pp.4239-3251

Badan Standarisasi Indonesia. 2015. Biodiesel. SNI 7182:2015.

Barabas, I dan Todorut, I. 2011. Biodiesel Quality, Standards, and Properties; In. Dr. Gisela Montero (Ed.) Biodiesel Quality, Emissions, and By-Product (pp.3-28). Croatia: InTech.

Darmawan, F.I dan I. Wayan Susila. 2013. Proses Produksi Biodiesel dari Minyak Jelantah dengan Metode Pencucian Dry-Wash Sistem. JTM Volume 02 Nomor 01: 80-87.

Dewan Energi Nasional. 2016. Outlook Energi Indonesia 2016. Jakarta: Dewan Energi Nasional.

Djenar, N.S dan Lintang, N. 2012. Esterifikasi Minyak Kemiri Sunan (Aleurites trisperma) dalam Pembuatan Biodiesel. Jurnal IImu-ilmu Hayati dan Fisik ISSN 1411-0903 Vol. 14 No. 3: 215-221.

Gerpen, J.V., B. Shanks, R Pruszko, D. Clements dan G. Knothe. 2004. Biodiesel Production Technology. Subcontractor Report Haryanto, B. 2013. Bahan Bakar
Alternatif Biodiesel (Bagian I. Pengenalan). Jurusan Teknik Kimia. Fakultas Teknik. Universitas Sumatera Utara.

Haryanto, B. 2013. Bahan Bakar Alteratif Biodiesel (Bagian I. Pengenalan). Jurusan Teknik Kimia, Fakultas Teknik, Universitas Sumatra Utara.

Hidayanto, E., Abdul, R., Heri, S. 2010. Aplikasi Portable Brix Meter untuk Pengukuran Indeks Bias. Berkala Fisika Vol. 13, No. 14: 113-118 ISSN: 1410-9662.

Hikmah, M.N. dan Zuliana. 2010. Pembuatan Metil Ester (Biodiesel) dari Minyak Dedak dan Metanol dengan Proses Esterifikasi dan Transesterifikasi (Skipsi). Teknik Kimia. Fakultas Teknik, Universitas Diponegoro, Semarang.

Kholiq, I. 2015. Pemanfaatan Energi Alternatif Sebagai Energi Terbarukan untuk Mendukung Substitusi BBM. Jurnal IPTEK Vol. 19 No.2.

Knothe, G., Gerpen, J.V., Krahl, J. 2005. The Biodiesel Handbook. United States of America: AOCS Press.

Nurjanah, S., Lestari, D.S., Widyasanti, A., dan Zain, S. 2015. The Effect of $\mathrm{NaOH}$ Concentration and Length of Trans-esterification Time on Characteristic of FAME from Reutealis trisperma (Kemiri Sunan). International Journal on Advanced Science Engineering Information Technology 5 (1): 52-56.

Nurjanah, S., Kramadibrata, A.M., Muhaemin, M., Handarto, Herwanto, T., Saukat, M., Rosalinda, S., Prijatna, D., Pratama1, M.H.B., Mardawati, E., Daradjat, W. dan Haryono. 2019. Study on Different Capacity of Transesterification Process in Biodiesel Production from Kemiri Sunan (Reutalis trisperma). International Conference on SMART CITY Innovation 2018. IOP Conf. Series: Earth and Environmental Science 248

Pawoko, E. 2009. Pengaruh Tahapan Proses Esterifikasi, Tranesterifikasi dan Netralisasi Terhadap Karakteristik Biodiesel dari Biji Kesambi (Schleichera oleosa L.). Fakultas Teknologi Pertanian. Institut Pertanian Bogor.

Pranowo, D., Muhamad, S., Bambang, P., Maman, H., Asif, A., Sumanto. 2014. Pembuatan Biodiesel dari Kemiri Sunan (Reutalis trisperma (Blanco) Airy Shaw) dan Pemanfaataan Hasil Samping. Jakarta: IAARD Press.

Sari, D.K. dan Lestari, R.S. Pengaruh Waktu dan Kecepatan pengadukan terhadap Emulsi Minyak Biji Bunga Matahari (Helianthus annuus L.) dan Air. Jurnal Integrasi Proses Vol 5 No 3 : 155-159 